The 16th Economic International Conference

New Challenges and Opportunities for the Economy 4.0,

May 7-8th, 2020, Suceava, Romania

\title{
Supporting the Sustainable Development of Companies Through the Use of Social Responsibility Practices in International Affairs
}

\author{
Camelia Catalina MIHALCIUC, Maria GROSU, \\ Anisoara Niculina APETRI
}

https://doi.org/10.18662/lumproc/ncoe4.0.2020/19

How to cite: Mihalciuc, C.C., Grosu, M., \& Apetri, A.N. (2020). Supporting the Sustainable Development of Companies Through the Use of Social Responsibility Practices in International Affairs. In C. Nastase (vol. ed.), Lumen Proceedings: Vol. 13. 16th Economic International Conference NCOE 4.0 2020 (pp. 206-225). Iasi, Romania: LUMEN Publishing House.

https://doi.org/10.18662/lumproc/ncoe4.0.2020/19 


\title{
Supporting the Sustainable Development of Companies Through the Use of Social Responsibility Practices in International Affairs
}

\author{
Camelia Catalina MIHALCIUC ${ }^{1 *}$, Maria GROSU², \\ Anisoara Niculina APETRI ${ }^{3}$
}

\author{
Abstract
}

\begin{abstract}
Corporate social responsibility became acquainted with a considerable evolution from a phenomenon little known and practiced by corporations, to a fundamental start-up priority, for both large and small companies. The involvement of corporations in solving global problems (such as global warming, low level of education, poverty eradication, equality between individuals and respect for buman rights) is a widespread trend nowadays. In this paper, the authors tried to reproduce the methods of implementing the measures of social responsibility of the companies, which contribute to supporting of the sustainable development, for some representative industrial branches (the industry and the services of the IT sector, the car construction industry, the food industry, the light industry, the mining industry, the cosmetic industry), by presenting the most relevant social responsibility campaigns encouraged by various companies. The corporate responsibility of the corporations has undergone an alert development, evolving from a little known phenomenon and, even less, practiced, towards a controversial subject, on the basis of which numerous works have been elaborated, constituting a fundamental strategic priority in the business process nowadays. Sustainable development and corporate social responsibility are compatible elements and points of view that need to be taken into consideration in the company's development strategy, with benefits for both the company, the environment, and all stakeholder categories.
\end{abstract}

Keywords: sustainable development; sustainable development goals, sustainable development strategy; corporate social responsability (CSR).

\footnotetext{
${ }^{1}$ Faculty of Economics and Public Administration, Department of Accounting, Auditing and Finance, “Stefan cel Mare” University Suceava, 720229, Romania, camelia.mihalciuc@usm.ro ${ }^{2}$ Economics and Business Administration, Department of Accounting, Business Information Systems and Statistics, Economics and Business Administration, "Alexandru Ioan Cuza" University of Iasi; 700505, maria lia24@,yahoo.com

${ }^{3}$ Faculty of Economics and Public Administration, Department of Accounting, Auditing and Finance, "Stefan cel Mare” University Suceava, 720229, Romania, anisoarad@,seap.usv.ro

* Corresponding author.
} 


\section{Introduction}

The three aspects of sustainability (economic, environmental and social) are translated into an approach to corporate sustainability [28], [49]. Corporate sustainability has been presented as the ultimate goal for corporations, which meet the needs of the present without compromising the ability of future generations to meet their own needs [49].

Reports on annual financial performance, sustainability and governance disclosure often fail to link the organization's strategy, financial performance, and environmental, social, and governance issues [36].

The need for corporate social responsibility can be seen as a way to give life to the company in the social landscape, contributing positively to receiving the same thing. Some critics see corporate social responsibility as an ideological movement meant to make the power of multinational corporations known, others as a theft from company's employees[33].

The move to corporate responsibility in business practice is a response not only to the negative environmental effects that the organization can have, but also to evaluate the economic and social effects of the organization on a global scale. In general, corporate sustainability focuses in the long term on the social and environmental economic impact of the organization and their interactive effect[52].

A corporation that successfully integrates sustainable development into its strategy, both in terms of its operation and the types of goods it sells, it is called a corporation that promotes sustainability. But it also depends on the intensity the corporation promotes the development of sustainability[7].

Nowadays, the concept of corporate social responsibility has several approaches, as pragmatic/ rational (companies take measures to adopt socially responsible behavior in order to obtain long-term competitive advantages); ethical (corporations are obliged to assume responsibilities beyond the economic sphere, taking into account their status within the community; in terms of social pressure (Corporations are required to keep up with the demands that come from the social sphere, from the community in which they operate) [21].

The corporate responsibility of corporations is present at the intersection of the sphere of corporation's influence with the aforementioned fields [37].

A corporation that successfully integrates sustainable development into its strategy, both in terms of its operation and the types of goods it sells, it is called a corporation that promotes sustainability. But it also depends on the intensity the corporation promotes the development of sustainability[7]. 


\section{Theoretical Background}

The specialized literature attempts in many ways to highlight the importance of corporate social responsibility in business strategy. Some authors even believe that "Corporate Social Responsibility initiatives must be integrated and internalized by the organization so that they are placed at the heart of the organization" [17], to gain benefits such as: improving corporate reputation, gaining customer confidence, increasing employee motivation or quota market.

In a recent study (2019) [53], a legal analysis is performed, considering whether foreign multinational companies working in Pakistan comply with CSR provisions and norms and, if so, to what extent these principles are respected. The study focuses more on identifying laws, rules and regulations in both international and national legal frameworks and aims to analyze the impact of CSR compliance especially on human rights, the environment and sustainable development. The results of the study show that the implementation and enforcement of these policies that support sustainable development are still in its early stages.

In another study [30], it was examined whether the CEE entities integrate economic, social and environmental aspects/policies in business activities in accordance with the principles of sustainable development that have a positive impact not only on the economic performance and on the company's relations with employees, business partners, customers, with the community and region of which it is part but also on the constant reduction of the impact on the environment through the sustainable development of human resources, community and society [39]. The authors concluded that business sustainability is high in CEE enterprises, and is linked to technological progress, paying special attention to pollution, health and safety.

Some studies confirm that economic entities publish social and environmental information only to be within the limits of legality in the field in which they operate. It has also been found that less performing entities publish performance-related information[3].

Applying the concept of sustainable development at the company level takes into consideration the corporate responsibility - resulting from the need for companies to adapt to survive in a company a context in which globalization and civic activism are increasingly changing radically[6]. This type of approach has been taken up at the level of large companies around the globe who are committed to sustainable or sustainable development and adopt reporting principles that are based on the concept of the triple balance sheet / objective[38]. 
This has been also mentioned by author Jeffrey [27]: "From the Brundtland report, the concept of sustainable development has passed beyond the original inter-generational framework, in order to be able to focus more on the objective of sustainable and inclusive economic growth." As the concept became wide larger, it focused more on economic development, social development and environmental protection for future generations [29].

An interesting approach is also given by author Shaker (2015) [42], who points out that sustainability is related to the equilibrium between human being and environment: "It has been suggested that the term sustainability should be seen as a target of human-ecosystem equilibrium (homeostasis), while sustainable development refers to the holistic approach and time processes that lead us to the end of sustainability".

Maon et al. (2010)[31] develops the phenomenon of corporate social responsibility during seven stages, divided into three cultural phases of the organization: reluctance to the phenomenon of corporate social responsibility (CSR phenomenon being ignored, or even rejected), understanding of the phenomenon (corporations becoming familiar with the principles of the phenomenon) and its incorporation into the landscape (corporations integrating the phenomenon into their own activity. This model is different from the existing ones, because it highlights the stage of development of the organizational culture (corporations being divided into those that accept and adopt socially responsible behavior and those that do not). This development is achieved by integrating corporate social responsibility programs and policies [5].

In recent years, corporate social responsibility has served as a mean used by companies to comply with the provisions regarding the environment and has contributed, at the same time, to increasing the competitiveness of the company[8]. For example, consumers are more attracted to buying products from companies that donate funds and goods to non-profit organizations and schools, use products that do not affect the environment, and practice volunteering.

The online presence, which is widespread today, can have both positive and negative effects on the company's image. The social responsibility that corporations prove or not, is part of the benchmarks that differentiate corporations, influencing the consumer's decision. Also, a good image also influences the decision of the employees to choose one company to the detriment of another. Businesses that ignore social responsibility have a minus from the beginning. The social reputation has a special impact on the company's image and, implicitly, on its profitability and success.

Most companies separate the section dedicated to Corporate Social Responsibility, within the sustainability reports in four major categories: the 
environment, employees, the retail market and society. Regardless of the succession and form in which the four concepts are addressed in the sustainability reports of companies, they are all defining elements in shaping the image of corporate social responsibility and, for this reason, most companies do not omit information about these four big spheres[2].

Lately, the big corporations present their business activity in a more transparent and responsible way. Thus, for businesses to be able to fulfill their obligations in accordance with the ethics of stakeholder responsibility, they must provide relevant, timely and understandable information about their activities through corporate reports. The company's conventional reports on annual financial performance, sustainability, and governance disclosures often fail to link the organization's strategy, financial results, and performance to environmental, social, and governance issues. Recognizing the inherent shortcomings of existing reporting models, there is an increasing trend of moving towards integrated reporting. A study in this direction was developed by Clayton, et al (2015) [9], showing the impact of the transition from sustainable reporting to integrated reporting on the nonfinancial disclosure of eight companies in South Africa using the content analysis of the annual reports.

According to the Global Reporting Initiative (GRI), sustainability reporting is the practice of measuring, disclosing, and being responsible for internal and external stakeholders in organizational performance for achieving the sustainable development goal. A sustainability report should provide a balanced and reasonable representation of the sustainability performance of the reporting organization, including positive and negative contributions" [24].

On the basis of this weaknesses background of the existing reporting models, integrated reporting appeared as a preferred approach (IRCSA, 2011)[23]. Integrated reporting is defined as "a holistic and integrated representation of the company's performance in terms of both its financing and its sustainability" (IoDSA)[26: 54].

In the last years, the corporate social responsibility has served as a means used by companies to respect the provisions related to the environment and has contributed, at the same time, to increase the competitiveness of the company[8].For example, consumers are more attracted to buying products from companies that donate funds and goods to non-profit organizations and schools, use products that do not affect the environment, and practice volunteering.

Corporate social responsibility became acquainted with a considerable evolution from a phenomenon little known and practiced by 
corporations, to a fundamental start-up priority, for both large and small companies[35].

In 2018, the focus was on eliminating inequality and workplace unpleasantness (inequality does not only mean promoting the female role, but also the equal treatment offered to employees regardless of culture, language, age, sexual orientation, disabilities and experiences). The year 2018 brings, in addition, from the perspective of corporate social responsibility, and a significant concern regarding the protection of personal data[33]. The forecasts for the following years, from the perspective of corporate social responsibility, provide: the need for specialists in the field of corporate social responsibility in order to be able to offer trainings or even to be employed; the concern to organize a completely ethical supply chain; measures to be taken in order to reduce the magnitude of natural disasters through better planning and restriction in terms of construction and development; concern to reduce or even eliminate carbon emissions by using alternative fuels (the electric car represents a relevant example in this respect). The new workforce is made up of those born since the second half of the 1990s and is expected to develop digitalization, flexibility in the workplace, freedom of choice, equality in rights and transparency in the workplace from them.

Sustainability assessment is a growing concern worldwide, with the implementation of the United Nations 2030 Agenda, thus finding the appropriate tools to ensure full coverage of environmental, social and economic issues in light of cultural, historical perspectives - retrospective and prospective - respectively institutional and to allow the participation of several stakeholders [50].

SDGs reflects a balanced agenda of economic, social and environmental goals and targets (In achieving the SDGs, countries will need to recognize and appreciate the existence of potential tradeoffs and develop ways of managing them. It should also identify complementarities that can promote significant progress[34].

\section{The methods of implementing the measures of social responsibility of the companies}

A Corporate Social Responsibility strategy invariably requires its implementation, a complex process consisting of: implementing management systems aimed at improving the quality of corporate governance and implementing the principles of sustainable development; organizing systemic interaction with stakeholders to maintain a balance of interests and minimize potential risks; forming a policy defining the 
objectives and a system of measures for the key areas of social responsibility of business; increasing the transparency and openness of the company; the usage of a clear system of performance indicators to measure the results of CSR implementation.

In table 1, the authors tried to reproduce the methods of implementing the measures of social responsibility of the companies, which contribute to supporting of the sustainable development, for some representative industrial branches by presenting the most relevant social responsibility campaigns encouraged by various companies, clearly defined in table 1.

Table 1. International practices of socially responsible companies

$\begin{array}{lll}\begin{array}{l}\text { Field of } \\ \text { activity }\end{array} & \begin{array}{l}\text { Representative } \\ \text { companies }\end{array} & \begin{array}{l}\text { Concerns, initiatives and actions that } \\ \text { support sustainable development }\end{array}\end{array}$






\begin{tabular}{|c|c|c|}
\hline & & $\begin{array}{l}\text { Microsoft employees completed such a program. } \\
\text { Within the measures for the Safety and Health of } \\
\text { Workers, as well as respect for Human Rights, two } \\
\text { entities are noted: Microsoft CARES (offers } \\
\text { personal and family counselling services, stress } \\
\text { management and help for children and the elderly) } \\
\text { and Microsoft Ergonomics (offers training } \\
\text { programs and special equipment regarding medical } \\
\text { needs). } \\
\text { Within the support measures of the local communities } \\
\text { there can be identified: }\end{array}$ \\
\hline & Sony [16] & $\begin{array}{l}\text { For the Next Generation are programs that aim to } \\
\text { ensure safe jobs and in conditions that do not } \\
\text { threaten the health status, specific to each type of } \\
\text { individual. } \\
\text { Road to Zero - its motivation is to reduce the human } \\
\text { impact on the environment. }\end{array}$ \\
\hline & Apple [43] & $\begin{array}{l}\text { Health education programs offered to women in } \\
\text { India and China; } \\
\text { Educational programs for employees to advance in } \\
\text { their careers; } \\
\text { Promoting Zero Waste Program; } \\
\text { Reduction of energy consumption and gas } \\
\text { emissions. }\end{array}$ \\
\hline \multirow[t]{2}{*}{$\begin{array}{l}\text { Car- } \\
\text { building } \\
\text { industry }\end{array}$} & BMW [48] & $\begin{array}{l}\text { The Ecological Education Development Project in schools - } \\
\text { promotes ecology among young people. } \\
\text { BMW China Culture Journey - promotes traditional } \\
\text { Chinese culture and supports sustainable } \\
\text { development and protection of intangible cultural } \\
\text { heritage. } \\
\text { BMW JOY Home - aims to help underprivileged } \\
\text { children in the underdeveloped regions of China } \\
\text { and enables both company employees, customers, } \\
\text { suppliers and associates to offer help. The company } \\
\text { aims to help by the mentioned campaigns over one } \\
\text { million people by } 2020 \text {. }\end{array}$ \\
\hline & $\begin{array}{l}\text { Mercedes } \\
\text { Benz [46] }\end{array}$ & $\begin{array}{l}\text { Daimler We Care aims to promote social progress all } \\
\text { over the world, considering that business oriented } \\
\text { towards social responsibility supports the evolution } \\
\text { of society. } \\
\text { Think Healthy, Thing Wealthy! - aims to solve the } \\
\text { issues regarding the health status of the population, } \\
\text { access to drinking water and facilitating access to } \\
\text { sanitation services. It also includes measures to }\end{array}$ \\
\hline
\end{tabular}


protect the environment and reduce global carbon dioxide emissions.

Better Today Better Tomorrow - aims to improve living conditions in India by: providing quality education and skills development, eradicating poverty, promoting equality, ensuring access to safe water, sanitation, reducing hunger and promoting a healthy lifestyle.

Volkswagen Helping Together - integrates refugees coming to [51] Europe.

CESMO (CorredorEcologico de la Sierra Madre Oriental) - protects biodiversity in Northeast Mexico.

$A$ day for the Future - an initiative implemented since 2002 by which employees voluntarily donate one day's salary, and these funds are granted to various social causes.

Casa del Sol - offers help to orphaned children or those who have been victims of abuse by offering medical support, both physically and mentally, for their reintegration.

Ford [44] The company is working on reducing carbon emissions with the initiators of the Paris Climate Accord;

It is considering launching 40 fully electric hybrid cars by 2022;

Better World initiated by the Ford Fund in partnership with the Global Giving Foundation aims: to associate with World Vision in Laos for cleaning the hospitals, to collaborate with the American Chamber Foundation Philippines in the Philippines to support communities through the Gawad Kalinga Development Agency, including repair of houses, education of children and medical activities, purchase of wheelchairs for people with disabilities in Africa, and so on.

LeviStrauss It aims to reduce the impact on the environment by \& Co [10] regulating human rights and environmental provisions.

Light industry
It promotes a campaign to reduce water consumption in its own manufacturing, having already saved one billion liters of water.

Promotes education, health, supports vocations, contributes to eradicating hunger and poverty, maintaining an ecological balance within favorable 
limits, conserving natural resources, as well as implementing rural development projects.

\begin{tabular}{ll}
\hline Patagonia & The company has a huge history of social \\
[12] & responsibility because since 1944 the organic cotton \\
& has been used and its quality was guaranteed by \\
& farmers.
\end{tabular}

It is working on granting a wage that allows a decent living for the workers, and this is not a simple minimum wage that barely guarantees the existence; It uses renewable energy sources, measures the carbon emissions and donates $1 \%$ of revenues from sales to environmental conservation efforts.

TOMS TOMS - Blake Mycoskie, the founder of the

\section{Shoes}

[11] company, offered 60 million pairs of shoes to needy children, based on the simple idea that for every pair of shoes sold, another pair was offered to a child in need.

TOMS Eyewear has cured the eyes of 400,000 people

TOMS Roasting Co. - provides drinking water for about 335,000 weeks in the territory of six countries,

TOMS Bag Collection supports bringing newborns to the world by providing training for those who attend births, and goods that the mother needs.

Coca Cola Starting with 2017, it promotes the female presence [54]

Food industry through training programs and mobile applications, special (launched for the first time in Malaysia) and thus offering the possibility of 660.000 women to become entrepreneurs.

ENGINE (Educating Nigerian Girls in New Enterprises program) conducted in partnership with the Department for International Development in the United Kingdom. It targets girls in Nigeria aged between 16 and 19, aiming to provide them with educational opportunities that translate into consistent economic benefits.

RAIN- Replenish Africa Initiative ensured access to drinking water in 39 African countries in 2017.

The motto of World Without Waste aims to use only recyclable materials until 2025 to reduce long-term pollution. Coca Cola has recently invested in trucks fueled by alternative fuels to reduce pollution (by $25 \%$ by 2020 ). 
In 2003, Coca Cola mobilized in Romania about 250 of its employees for the rehabilitation of parks, children's playgrounds and painting of public fences.

McDonald's RMHC (Ronald McDonald's House Charities) -
[19] supports local communities by providing free accommodation to children with serious illnesses who need long-term treatment.

McDonald's Hamburger University - founded in 1961, has 7 campuses worldwide and offers training programs to managers and employees.

Operation Smile - dates from 1999, when a team of plastic surgeons doctors sponsored by the company operated at "GrigoreAlexandrescu" hospital in Bucharest about 200 children with congenital facial malformations.

The entire McDonald`s chain invests in special equipment to reduce energy consumption.

Kraft Heinz To Be the Best Food Company, Growing A Better World [25] seeks to improve the social environment and hold the leading position in the field.

Together for Children (2002) renovated six pediatric hospitals in Romania, allocating a total of $\$ 200,000$ as a result of the sale of the company's products.

The company wishes that the methods of procurement of palm oil should take place in an ethical manner, avoiding deforestation and forests with a significant degree of conservation, strictly respecting the law and human rights, being strictly prohibited the exploitation of children or forced labor.

Other Sustainable Agriculture Initiative $(S A I)$ - promotes comprehen sustainability within the agricultural system.

sive CSR The Danish Food and Drink Federation - sets high programs in quality standards for food and beverages.

the food The European Food Sustainable Consumption and industry Production Round Table - initiative from the public[22] private sphere, which promotes sustainable consumption and production, especially in Europe, but also establishes measures for the protection of the environment.

Fairtrade International (FO) - aims to create better working conditions for farmers and measures to protect the environment. 


\begin{tabular}{|c|c|c|}
\hline \multirow{3}{*}{$\begin{array}{l}\text { Mining } \\
\text { industry }\end{array}$} & $\begin{array}{l}\text { Glencore } \\
{[47]}\end{array}$ & $\begin{array}{l}\text { It is involved in actions to bring benefits to the } \\
\text { company by hiring residents in their own company } \\
(80 \% \text { of employees are residents, and } 63 \% \text { of } \\
\text { managers as well) and by promoting the local } \\
\text { economy (invests over } 15.1 \text { billion dollars in local } \\
\text { suppliers and } 134 \text { millions of dollars in } \\
\text { infrastructure). } \\
\text { It tries to reduce the impact that comes from the } \\
\text { corporation on the environment, takes measures to } \\
\text { maintain the health and well-being, both of the } \\
\text { employees and of the surrounding local } \\
\text { communities. }\end{array}$ \\
\hline & $\begin{array}{l}\text { Rio Tinto } \\
\text { Group [13] }\end{array}$ & $\begin{array}{l}\text { The mining company argues that commitment to } \\
\text { sustainable development is an essential factor for } \\
\text { their business. } \\
\text { The areas targeted for improvement are: natural } \\
\text { resource management, climate change, local } \\
\text { employment, human rights defense, donations, } \\
\text { supporting the education system and so on, the } \\
\text { most relevant example being the way it is } \\
\text { approached. biodiversity conservation. } \\
\text { In } 1993 \text { they associated with EarthWatch Institute } \\
\text { (Environmental Charity Foundation, founded in } \\
\text { 1971 - United States of America, providing a } \\
\text { unique model of science to citizens to raise funds } \\
\text { and recruit people to participate in field research to } \\
\text { understand "nature's response" to accelerating } \\
\text { global change, and this involves over } 100,000 \text { hours } \\
\text { of research annually) and involves } 24 \text { employees in } \\
\text { this program. }\end{array}$ \\
\hline & $\begin{array}{l}\text { Mott } \\
\text { Macdonald } \\
{[40]}\end{array}$ & $\begin{array}{l}\text { They discovered a number of strategies and tools to } \\
\text { support a program to inform the population about } \\
\text { HIV and methods to prevent this disease. } \\
\text { Under the motto Equality, Diversity and Inclusion } \\
\text { (EDI) the company advocates for a favorable } \\
\text { workplace climate, ethical behavior, collaboration } \\
\text { with suppliers who act socially responsible, } \\
\text { encourages employees to contribute to the well- } \\
\text { being of the community. }\end{array}$ \\
\hline $\begin{array}{l}\text { Cosmetic } \\
\text { industry }\end{array}$ & $\begin{array}{l}\text { Nu Skin } \\
{[15]}\end{array}$ & $\begin{array}{l}\text { It initiates a movement to reduce hunger in Malawi } \\
\text { (a small country in Africa, severely affected by } \\
\text { hunger and poverty). Unlike TOMS and Juntos, } \\
\text { this company does not make donations, but offers } \\
\text { consumers the opportunity to buy and donate food }\end{array}$ \\
\hline
\end{tabular}


to needy children, an initiative that provides food for 100.000 children daily.

\begin{tabular}{ll}
\hline Colgate- & They participate positively in the social \\
Palmolive & environment through the following measures: \\
[45] & reducing the risk of employees' illness by $15 \%$; \\
& encouraging a healthy lifestyle; ensuring a safe \\
& working environment for employees; offers \\
& trainings and products to employees and users; \\
& collaborates with animal shelters, ensuring a shelter \\
& for over 2 million dogs and cats; brings to the \\
& society the importance of constant hand washing. \\
& Volunteers through Colgate Cares Day and Colgate \\
& Bright Smiles, Bright Futures. \\
\hline Avon & Avon Breast Cancer Crusade, a brand that stands out \\
Cosmetics & for breast cancer measures, comprising 58 states, \\
& raising $\$ 740$ million for breast cancer research, \\
& education and care. \\
& Speak Out Against Domestic Violence, a campaign \\
& aimed at reducing domestic violence, based on \\
& donations and fundraising. \\
& They stand out ethical behavior, social inclusion, \\
& enhancing the female role in society, reducing \\
pollution and deforestation.
\end{tabular}

Source: own elaboration

Information technology has been rising lately in the context of fierce competition and, implicitly, numerous innovations. We can say that the companies in the technology industry would be most able to implement social responsibility programs, having the advantage of the latest technological discoveries, which facilitate their activity, these corporations being suitable to conclude collaborations/coalitions in order to design a better future. Large IT companies say they are investing considerable amounts in order to discover renewable energy sources, they are investing in the education sector and they are supporting young people in finding a job, they are taking measures to reduce water consumption and carbon emissions, they are investing in the medical sector, advocates for well-being and safety at work[3]. The technological sector can also be used effectively to influence the public's decision, in order to act in favor of developing the social environment.

It is well known that the car-building building industry is among the most developed industries in the world, which is why, the extent of its social responsibility, through the measures adopted, is more significant. These 
companies maintain a stable balance between a successful business model and the support for social causes[55]. Because the car-building industry is primarily responsible for the high level of pollution, most of the companies in this branch are trying, first and foremost, to demonstrate social responsibility, to reduce carbon dioxide emissions, and also to support the cross-cultural diversity, innovation, mobility and social inclusion, implementation of instructional programs for children regarding the circulation on public roads and creation of new generations of engineers [32].

The light industry is constantly moving and in a permanent production process, because the life cycle of the goods produced by this industrial branch is not a long one, and the trends are constantly changing. Being a sector that encompasses a large percentage of the existing workforce, companies in this industry must show a constant concern for the well-being of employees, their health and safety at work, not only within the company, but also within the entire supply chain[41]. Also, the representatives of the light industry are constantly supporting the development of the education system, the obliteration of the poverty and hunger, the rural development and the underprivileged nations. The entire process of producing and selling textiles affects the social environment in various ways, the most significant effects being: high carbon dioxide emissions (because they use pesticides, oils, paint), large quantities of textiles are recycled (as a result of the cycle of short-living products), and also serious health problems, such as bulimia and anorexia.

If we refer to the food industry, this is one of the most problematic issue, both for developing countries, where hunger is an extremely delicate subject, and for a number of other states, where obesity gathers victims. For this reason, companies in the food industry are developing social responsibility programs, especially for the two extremes that dominate: reducing obesity or eradicating hunger [1]. In the context of corporate social responsibility, the food industry is mainly related to the impact on the environment (for example, consumption and waste of energy and water, environmental protection) and to the working conditions. The companies in this industry also support: donations, capitalization food waste, reducing hunger, promoting responsible drinking, facilitating access to safe drinking water, educational campaigns, reducing carbon dioxide emissions, accommodation for the needy, reducing tobacco consumption, and promoting animal welfare [22].

The companies operating in mining industry participate to the improvement of the social environment by: making available to the community some jobs, promoting and respecting human rights and creating favorable conditions for employees in the workplace, this topic being a 
sensitive and frequently discussed topic resulting from a large number of accidents. The companies also support: infrastructure development, providing assistance to the needy (food, shelter), educational and recreational programs, investments in the medical sector, biodiversity conservation, supporting sustainable development and so on.

Within the cosmetic industry, corporate social responsibility plays a particular role, this being demonstrated by the way this phenomenon manifests itself in companies, being concerned with the social environment, starting from the fact that it uses eco ingredients, does not test the products on animals, does not adopt discriminatory behavior towards customers in terms of product quality and strictly respects human rights and freedoms.

\section{Conclusions}

Although the same directions for supporting sustainable development by companies are pursued (environment, employees, ethical behavior, volunteering, community, etc.), each industry has certain particularities, having a different impact on the social environment and, implicitly, the adopted responsibility measures being different from one industrial branch to another, and thus the companies will follow to a greater extent certain aspects depending on the specific activity.

Being aware of the importance given by consumers to social responsibility, most companies also focus their efforts in this direction, the results contributing to improving the image of the company and, of course, to the welfare of the company in general.

The corporate responsibility of the corporations has undergone an alert development, evolving from a little known phenomenon and, even less, practiced, towards a controversial subject, on the basis of which numerous works have been elaborated, constituting a fundamental strategic priority in the business process nowadays.

\section{References}

[1] Aghashahi B, Abdul Rasid SZ, Sarli M, Ah Mand A. Corporate social responsibility reporting of food industry major players, Interdiscip. J. Contemp. Res. Bus.; 2013, 5(2): 751-761.

[2] Alińska A, Filipiak B, Kosztowniak A. The Importance of the Public Sector in Sustainable Development in Poland, Sustainability; 2018 10(9): 3278.

[3] Aldaz M, Alvarez I, Calvo J.A. Non-financial reports, anti-corruption performance and corporate reputation, Rev. Bras. Gest. Neg.; 2015, $17(58)$ : 1321-1340. 
[4] Banerjee, S. B. Corporate Social Responsibility: The Good, the Bad and the Ugly, Crit. Sociol; 2008, Jan., 34 (1): 51-79.

[5] Banerjee SB. Corporate Social Responsibility: The Good, the Bad and the Ugly, 2007th ed. Cheltemham UK, Northampton MA, USA: Edward Elgar Publishing, 2009.

[6] Belaşcu L. Responsabilitatea corporativă şi performanțele companiilor multinaționale, în Studii post-doctorale în economie, volumul 5, Studii şi cercetări privind impactul globalizării asupra structurii şi dinamicii economiilor. Bucharest, Romania: Romanian Academy Publishing House; 2013, pp. 66-130.

[7] Benveniste D, Griffiths J, Sutton P. Sustainability and sustainable development. Sydney, 2000.

[8] Boulouta I, Pitelis C.N. Who needs CSR? The impact of corporate social responsibility on national competitiveness, Journal Bus. Ethics; 2014, 119 (3): 349-364.

[9] Clayton AF, Rogerson JM, Rampedi I. Integrated reporting vs. sustainability reporting for corporate responsibility in South Africa. Bulletin of Geography. Socio-Economic Series; 2015; 29: 7-17.

[10] Corporate Information, Levi`s. Available from: https://www.levi.in/CSRpolicy.html (accessed on 28 November 2019).

[11] Corporate Responsibility at TOMS, TOMS Company Info. Available from: https://www.toms.com/corporate-responsibility (accessed on 28 November 2019).

[12] Corporate Responsibility, Patagonia. Available from: https://www.patagonia.com/corporate-responsibility.html (accessed on 28 November 2019).

[13] Corporate Social Responsibility of Rio Tinto. Section Management, UKEssays.com, 2017. Available from: https://www.ukessays.com/essays/management/corporate-socialresponsibility-of-rio-tinto-management-essay.php (accessed on 28 November 2019).

[14] Corporate Social Responsibility, Avon. Available from: https://courses.lumenlearning.com/boundless-

management/chapter/corporate-social-responsibility/ (accessed on 28 November 2019).

[15] Creating Smiles Worldwide, $\mathrm{Nu}$ Skin. Available from: https://www.nuskin.com/content/corpcom/en US/newsroom/press kits/c orporate socialresponsibilitypresskits.html (accessed on 28 November 2019).

[16] CSR / Environment, Sony. Available from: https://www.sony.net/SonyInfo/csr/ (Accessed on 28November 2019).

[17] Dey M, Sircar S. Integrating Corporate Social Responsibility Initiatives with Business Strategy: A Study of Some Indian Companies., IUP J. Corp. Gov., 2012, 11 (1): 36-51. 
[18] Dudovskiy J. Microsoft Corporate Social Responsibility (CSR): a Brief Overview, Research-Methodology, 10-Feb-2019. Available from: https://research-methodology.net/microsoft-corporate-social-responsibilitycsr/ (accessed on 26 November 2019)

[19] Dudovskiy J. Overview of McDonalds CSR, Research-Methodology, 18-Feb2016. [CrossRef].

[20] Dudovskiy J. Google Corporate Social Responsibility (CSR), ResearchMethodology, 08-Jun-2017. Avaible from: https://researchmethodology.net/google-corporate-social-responsibility-csr/ (accessed on 26 November 2019)

[21] Farcane N, Bureana E. History of „Corporate Social Responsibility” Concept, Ann. Univ. Apulensis Ser. Oeconomica; 2015, 17: 31 - 48.

[22] Food Industry. CSR Compass. Available from: https://www.csrcompass.com/food-industry (accessed on 28 November 2019).

[23] Framework for Integrated Reporting and the Integrated Report. Discussion Paper; 2011. Available from: http://integratedreportingsa.org/ircsa/wpcontent/uploads/2017/05/IRC-of-SA-Integrated-Reporting-Guide-Jan11.pdf (accessed on 28November 2019).

[24] GRI (Global Reporting Initiative), 2011: Sustainability Reporting Guidelines, Version 3.1, Amsterdam: Global Reporting Initiative. - Google Search. Available from: https://www.google.com/search?q=GRI+(Global+Reporting + Initiative) $\% 2$

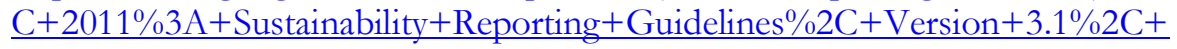
Amsterdam $\% 3 \mathrm{~A}+$ Global+Reporting+Initiative.\&rlz=1C1SQJL enRO870RO $\underline{870 \& o q=G R I+(\text { Global }+ \text { Reporting }+ \text { Initiative }) \% 2 \mathrm{C}+2011 \% 3 \mathrm{~A}+\text { Sustainability }}$ + Reporting + Guidelines $\% 2 \mathrm{C}+$ Version $+3.1 \% 2 \mathrm{C}+$ Amsterdam $\% 3 \mathrm{~A}+\mathrm{Global}+\mathrm{R}$ eporting + Initiative $. \& a q s=$ chrome. .69157 .2410 j0j8\&sourceid $=$ chrome\&ie $=U T$ F-8 (accessed on 28 November 2019).

[25] Growing a Better world. Sustainable Business Practices, Kraft Heinz. Available online: https://www.kraftheinzcompany.com/corporate-socialresponsibility.html (accessed on 28 November 2019).

[26] IoDSA (Institute of Directors Southern Africa). King Report on Corporate Governance for South Africa Johannesburg: Institute of Directors in Southern Africa," $2009 . \quad$ Available online: https://www.google.com/search?rlz=1C1SQJL enRO870RO870\&sxsrf=AC YBGNRbbE1WxMvi8VIEywI1EMMa OtgDw\%3A1574933985753\&ei=4Z XfXebULcTawALd 5O4Bg\&q=IoDSA+\%28Institute+of+Directors + South ern+Africa $\% 29+2009 \% 3 \mathrm{~A}+$ King + Report+on + Corporate + Governance + for + South + Africa + Johannesburg $\% 3 \mathrm{~A}+$ Institute + of + Directors + in + Southern + Africa.\&oq $=$ IoDSA $+\% 28$ Institute + of + Directors + Southern + Africa $\% 29+200$ $\underline{9 \% 3 \mathrm{~A}+\text { King }+ \text { Report }+ \text { on }+ \text { Corporate }+ \text { Governance }+ \text { for }+ \text { South }+ \text { Africa }+ \text { Joha }}$ nnesburg $\% 3 \mathrm{~A}+$ Institute + of + Directors $+\mathrm{in}+$ Southern + Africa.\&gs $1=$ psyab.3..35i362i39110.121703.126079..128376..1.0..1.107.209.0j2.....3...1j2..gws- 
wiz.....10..0i7i30.6Bn2rMr39Jg\&ved=0ahUKEwimyY mzozmAhVELVAKHd3_BGcQ4dUDCAs\&uact=5. (accessed on 28 November 2019).

[27] Jeffrey S. The Age of Sustainable Development. Columbia University Press; 2015.

[28] Jonikas D. Conceptual framework of value creation through CSR in separate member of value creation chain, Bulletin of Geography. Socio-economic Series; 2013, 21: 69-78.

[29] Keeble B. The Brundtland report: Our common future, Medicine and War; 1988 Jan. 4 (1): 17-25.

[30] Kovačič A. Implementation of Corporate Social Responsibility in Central Europe, Management of Sustainable Development, Sciendo; 2018 Dec, 10 (2): 87-98.

[31] Maon F, Lindgreen Am Swaen V. Organizational stages and cultural phases: A critical review and a consolidative model of corporate social responsibility development, International Journal of Management Reviews; 2010, 12 (1): 20 38.

[32] Martinuzzi, A.; Kudlak, R.; Faber, C.; Wiman, A. CSR activities and impacts of the automotive sector, Research Institute for Managing Sustainability (RIMAS), Vienna University of Economics and Business Franz Klein Gasse, Vienna, Austria; 2011 pp. 1-1190.

[33] McPherson P. Corporate Social Responsibility (CSR) trends to look for in 2018. Forbes, 2018.

[34] Mensah J. Sustainable development: Meaning, history, principles, pillars, and implications for human action: Literature review. Cogent Social Sciences; 2019, 5(1), 1653531.

[35] Mihalciuc C. Corporate social responsibility and sustainable development complex phenomena of the modern corporate environment. European Journal of Accounting, Finance \& Business; 2019, Volume X/2019, Issue (XX), ISSN 2344-102X.

[36] Mihalciuc C. Corporate social responsibility strategies and sustainability reports in supporting sustainable development, European Journal of Accounting, Finance \& Business; 2019, Volume IX/2019 Issue (XIX), ISSN 2344-102X.

[37] Mihalciuc C, Iftinchi D. Short forward in the evolution of the corporate social responsability concept, European Journal of Accounting, Finance \& Business; 2019, Volume XI/2019, Issue (XXI), ISSN 2344-102X.

[38] Mihalciuc, C, Apetri A. N. Measuring and Reporting Non-Financial Performance of Socially Responsible Companies, in 2019 Basiq International Conference: New Trends in Sustainable Business and Consumption, V. Dinu, Ed. Bucuresti: EdituraAse; 2019, pp. 507-514.

[39] Paths to Our Digital Future - 2017 Internet Society Global Report, Internet Society 2017 Global Internet Report. Available from: https://future.internetsociety.org/2017/ (accessed on 28 November 2019). 
[40] Running a Sustainable Business. Mott MacDonald, Section Sustainability. Available from: https://www.mottmac.com/sustainability (accessed on 28 November 2019).

[41] Sajn N. "Environmental impact of the textile and clothing industry What consumers need to know," Environmental impact of the textile and clothing industry: What consumers need to know - Think Tank; 2019. Available from: http://www.europarl.europa.eu/thinktank/en/document.html?reference=EP RS_BRI\%282019\%29633143 (accessed on 28 November 2019).

[42] Shaker RR. "The spatial distribution of development in Europe and its underlying sustainability correlations," Applied Geography; 2015, 63: 304-314.

[43] Supplier Responsibility, Apple. Available from: https://www.apple.com/supplier-responsibility/ (Accessed on 28November 2019).

[44] Sustainability Report 2018/19, Ford Motor Company. Available from: https://corporate.ford.com/microsites/sustainability-report-201819/index.html (accessed on 28 November 2019).

[45] Sustainability, Colgate-Palmolive. Available from: https://www.colgatepalmolive.com/en-us/core-values/sustainability (accessed on 28 November 2019).

[46] Sustainability, Daimler. [Online]. Available from: https://www.daimler.com/sustainability/ [Accessed: 28-Nov-2019].

[47] Sustainability, Glencore. Available from: https://www.glencore.com/sustainability (accessed on 28 November 2019).

[48] Sustainable Investments with the Know-How of the BMW Group. Social Commitment. Available from: https://www.bmwgroup.com/en/responsibility/corporate-citizenship/socialcommitment.html (accessed on 28 November 2019).

[49] Thomsen C. Sustainability (world commission on environment and development Definition), Encycl. Corp. Soc. Responsib.; 2013, pp. 2358 2363.

[50] Villeneuve C, Tremblay D, Riffon O, Lanmafankpotin G, Bouchard S. A systemic tool and process for sustainability assessment, Sustainability; 2017, 9, (10): 1909.

[51] Macaityte V, Virbasiute G. Volkswagen Emission Scandal and Corporate Social Responsibility - A Case Study, Business Ethics and Leadership. Armg Publishing; 2018; 2 (1): 6-13.

[52] White GV. Sustainability reporting: Managing for wealth and corporate health. New York: Business Expert Press; 2009.

[53] Yu S, Zia-ud-Din M, Dilawer R, Ban X. Corporate Social Responsibility in Pakistan: A Legal Perspective with Reference to MNEs, Journal Polit. Law; 2019, 12(3): 87.

[54] 2017 Sustainability Report, Coca-Cola Journey. Available from: https://www.coca-colacompany.com/2017-sustainability-report (accessed on 28 November 2019). 
Camelia Catalina MIHALCIUC, ... | Lumen Proceedings 13 | NCOE4.0 2020

[55] 2019 Automotive Sustainability Report - SMMT. Available from: https://www.smmt.co.uk/industry-topics/sustainability/ (accessed on 28 November 2019). 